\title{
Corynespora Leaf Blight of Cotton in Brazil and Its Management
}

\author{
Rafael Galbieri', Dalt C. E. B. Araújo', Leimi Kobayasti², Larissa Girotto, \\ Janaina N. Matos ${ }^{3}$, Mariana S. Marangoni ${ }^{3}$, W. P. Almeida ${ }^{3}$, Yeshwant R. Mehta ${ }^{3}$ \\ ${ }^{1}$ Instituto Mato-Grossense do Algodão (IMA), Primavera do Leste-MT, Tropical Agriculture-FAMEVZ/UFMT, \\ Cuiabá, Brazil \\ ${ }^{2}$ Universidade Federal de Mato Grosso-UFMT, Cuiabá, Brazil \\ ${ }^{3}$ Instituto Agronômico do Paraná-IAPAR, Londrina, Brazil \\ Email: "yeshwantrmehta@gmail.com
}

Received 21 October 2014; revised 20 November 2014; accepted 3 December 2014

Copyright (C) 2014 by authors and Scientific Research Publishing Inc.

This work is licensed under the Creative Commons Attribution International License (CC BY).

http://creativecommons.org/licenses/by/4.0/

\begin{abstract}
In recent years, Corynespora leaf blight is on the increase in cotton and has become an important disease in the State of Mato Grosso, Brazil. It attacks several plant species including soybean. It is not yet known whether the same strain of this pathogen attacks both the crops. The objectives of the present investigation were to verify the genotypic and phenotypic variation between the isolates attacking cotton and soybean and to verify the sources of resistance in cotton. Differential response of 23 cotton genotypes was studied under glasshouse conditions using mixture of two randomly selected isolates of $\boldsymbol{C}$. cassiicola of cotton in equal proportion. Genotypic variation among three cotton and two soybean isolates was studied using ERIC/REP-PCR and rDNA molecular techniques. With one exception, all the cotton genotypes tested so far were susceptible to $C$. cassiicola isolates of both cotton and soybean. Similarly, results of both molecular techniques indicated that the $C$. cassiicola isolates attacking cotton and soybean belong to the same strain of the pathogen in Brazil. Since Corynespora blight is a newly immerging disease of cotton and soybean in Brazil, integration of crop rotation and the sanitary practices are suggested to manage the disease.
\end{abstract}

\section{Keywords}

Gossypium hirsutum, Corynespora cassiicola, Target Spot

\section{Introduction}

Corynespora leaf blight of cotton (Gossypium hirsutum), also referred as “Target spot”, is caused by Corynes"Corresponding author.

How to cite this paper: Galbieri, R., Araújo, D.C.E.B., Kobayasti, L., Girotto, L., Matos, J.N., Marangoni, M.S., Almeida, W.P. and Mehta, Y.R. (2014) Corynespora Leaf Blight of Cotton in Brazil and Its Management. American Journal of Plant Sciences, 5, 3805-3811. http://dx.doi.org/10.4236/ajps.2014.526398 
pora cassiicola (Berk \& Curt.) Wei. Other than cotton the pathogen attacks several crop plants. Corynespora leaf blight occurs on cotton in several countries and was reported for the first time in 1959 in the State of Alabama, USA [1]. In recent years it is reported to be a serious problem in the USA [2] [3].

The disease was also reported for the first time on soybean in Bolivia in 1994 and on cotton in the State of Mato Grosso, Brazil in 1995 [4] [5]. In the State of Mato Grosso, during the crop cycle of 2004-2005 severe incidence on cotton cv. CNPA ITA 90 was observed [5]. The disease is now spread across the cotton growing areas of Brazil and especially the State of Mato Grosso, and has emerged as an important disease causing heavy yield losses. Accurate information on yield losses are not available.

The pathogen causes infection on all above ground parts of cotton. Symptoms on the cotyledonary leaves appear as small circular spots. Infection on hypocotyls may cause seedling death. The foliar phase of the disease is characterized as small circular spots, varying between $2 \mathrm{~mm}$ and $10 \mathrm{~mm}$. The well developed lesions are necrotic and show typical "target spot" symptoms, with some depression at the center of the lesion [5]. In severe cases of infection the lesions coalesce and the leaves show severe necrosis followed by complete premature senescence and death of the leaf (Figure 1). In artificial inoculations the lesions can be observed girdling the petiole (Figure 2). Frequently, more bolls near the ground level get infected than the bolls formed at higher levels, probably because of the high humidity and the presence of soil inoculum. Severely infected bolls lose quality and produce infected seed.

In the State of Mato Grosso, most of the cotton is cultivated in sequence with soybean each year in the same field. Since both the crops are attacked by C. cassiicola, there is a generalized concern among the cotton and soybean growers to verify whether the same strain of this pathogen attacks both the crops. Jones (1961) [1], reported that the $C$. cassiicola isolates causing leaf spots on cotton and on soybean were identical. However, so far in Brazil there is no report about the similarity among the C. cassiicola isolates from cotton and soybean. Com-

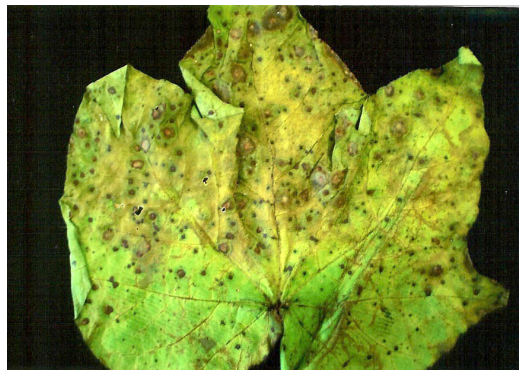

(a)

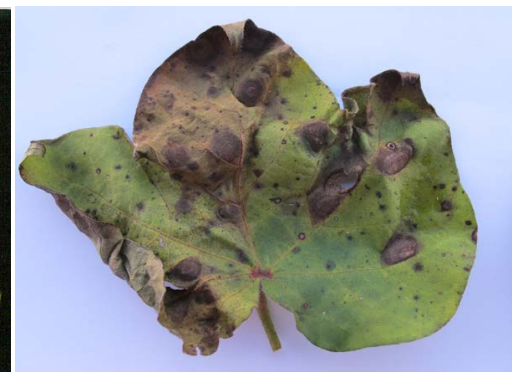

(b)

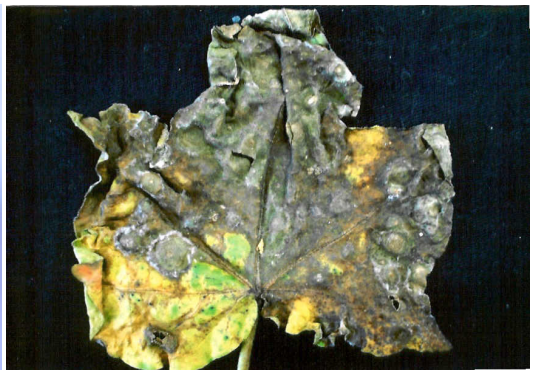

(c)

Figure 1. Corynespora leaf blight of cotton. (a) Initial symptoms; (b) Well developed lesions showing "Target spot" symptoms; (c) Severely infected leaf showing necrosis, severe yellowing and premature death of the leaf.

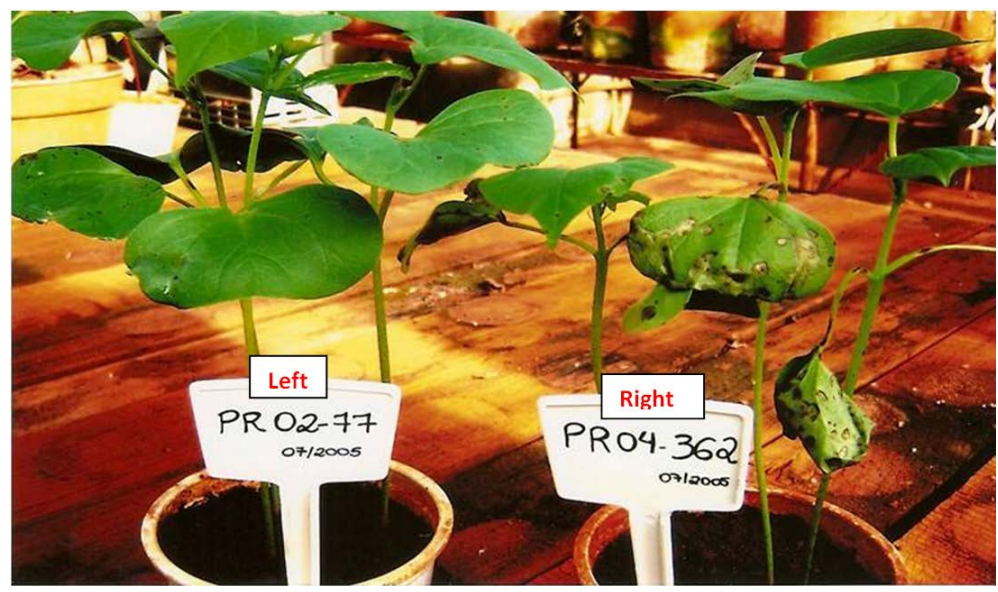

Figure 2. Symptoms of Corynespora cassiicola on cotton leaves 10 days after inoculation. Right-Susceptible genotype PR 04-362; Left-Resistant geneo- type PR 02-77. 
prehensive studies on host specialization and pathogenic diversity of $C$. cassiicola were presented by Dixon et al. (2009) [6]. The objectives of the present investigation were to verify the genotypic and phenotypic variation between the isolates attacking cotton and soybean and to verify the sources of resistance in cotton.

\section{Material and Methods}

\subsection{Disease Samples}

Infected leaf samples of cotton and soybean were collected from their respective commercial fields during 2010 and 2012, and five monosporic isolations (three from cotton and two from soybean) were made. After confirming the pathogenicity on their respective hosts the isolates were later stored at $5^{\circ} \mathrm{C}$ on Potato Dextrose Agar (PDA) medium for further studies.

\subsection{Phenotypic Variation}

Differential response of 23 cotton genotypes was studied under glasshouse conditions using mixture of two randomly selected isolates of $C$. cassiicola of cotton in equal proportion. The trial was conducted in a randomized block design in six replications with four plants per replication. Fungal cultures were grown on PDA for 10 days and the fungal growth was scraped and suspended in sterile distilled water. The inoculum was adjusted to $5 \times$ $10^{3}$ conidia $\mathrm{mL}^{-1}$ and a drop of Tween 20 was added. Control plants were sprayed with sterile distilled water. Twenty five days old plants were inoculated till run-off and were incubated in a growth chamber for $24 \mathrm{~h}$ at $21^{\circ} \mathrm{C}$ and under alternating cycle of $12 \mathrm{~h}$ dark/12 h light. Later the plants were transferred to the glasshouse bench where humidity was not controlled. Twenty four plants of each genotype were inoculated. Disease rating was made ten days after inoculation using a visual disease rating scale of $0 \%-100 \%$ Leaf Area Infected (LAI).

\subsection{Cross Inoculation Studies}

Cross inoculation studies with three cotton isolates IMA 262, IMA 358, IMA 374, originated from three locations such as Alto Taquari, Primavera do Leste and Campo Verde, respectively, and two soybean isolates IMA 275 and IMA 383, originated from Campo Verde and Primavera do Leste, respectively, were performed on six cotton cultivars and six soybean cultivars under glasshouse conditions. Sixteen plants of each genotype were inoculated. Average disease severity of over 10\% LAI was arbitrarily considered as susceptible reaction.

\subsection{Genotypic Variation}

Genotypic variation among three cotton and two soybean isolates was studied using two molecular techniques such as ERIC/REP-PCR and internal transcribed spacer (ITS) region of ribosomal DNA (rDNA), and are described as follows. Genomic DNA was extracted as described in earlier studies (7).

ERIC and REP-PCR: We used Enterobacterial Repetitive Intergenetic Consensus (ERIC) and Repetitive Extragenic Palindromic Sequence (REP) PCR fingerprinting. Use of the ERIC/REP-PCR was originally reported for genomic fingerprints of phytopathogenic bacteria. In the recent years, ERIC/REP-PCR is also being used do detect genetic variability among fungal pathogens of several crops [7]. The sequences of the primers are ERIC1R -5'-ATGTAAGCTCCTGGGGTTCAC-3'; ERIC2-5'-AAGTAAGTGACTGGGGTGAGCG-3'; REP1R-15'-IIICGICGICATCIGGC-3'; REP2-1-5'-ICGICTTATCIGGCCTAC-3'. PCR reactions were performed in a volume of $25 \mu \mathrm{L}$ containing $10 \mathrm{mM}$ Tris- $\mathrm{HCl}(\mathrm{pH}$ 8.3), $50 \mathrm{mM} \mathrm{KCl,} 2 \mathrm{mM} \mathrm{MgCl}, 200 \mu \mathrm{M}$ dNP, $1.3 \mu \mathrm{L}$ of 1\% bovine serum albumin, 50 pmol of each primer, 100 ng of genomic DNA, and $1 \mathrm{U}$ of Taq polymerase (Invitrogen). Amplification was performed in a Thermal Cycler (MJ research, Inc., Watertown, MA, USA) and the PCR products $(25 \mu \mathrm{L})$ were submitted to electrophoresis in $2.0 \%$ agarose gels and stained with ethidium bromide. For ERIC/REP PCR each isolate was tested in duplicate.

ITS rDNA: The isolates were assessed using the PCR-RFLP procedure as described earlier [7]. The amplification products were digested using randomly selected six restriction enzymes (Alu I, Bgl I, Dra I, EcoR I, Hind I and Hinf I). The products of digestion were separated through the gel electrophoresis in $2 \%$ agarose. The reaction was analyzed in a total volume of $20 \mu \mathrm{L}$ containing $1.5 \mu \mathrm{L}$ of restriction enzyme. DNA digestion was performed according to the instructions of the supplier. All the amplifications and digestions were repeated once to make sure the repeatability of the reactions. 


\section{Results and Discussion}

Under artificial glasshouse inoculations conducted as early as in 2005 [5], one genotype of cotton (PR02-77) was identified as resistant (Figure 2). Later, all the cotton genotypes tested under the present investigation showed susceptible reaction. High disease intensities were recorded for all the cotton cultivars and no resistance was observed (Table 1 \& Table 2), whereas the genotype PR02-77 maintained its resistance as verified in a separate test under glasshouse conditions.

Similar banding patterns were observed for cotton and soybean isolates using ERIC/REP-PCR. Since our objective was to verify if the $C$. cassiicola isolates attacking cotton and soybean belong to the same strain of the pathogen, only a few isolates from each crop were used during the present study. While there existed some genotypic variation within the cotton and within the soybean isolates, no clear indication of variation was observed between the cotton and soybean isolates (Figure 3).

The size of the amplified DNA fragment was around $600 \mathrm{bp}$. None of the restriction enzymes were informa-

Table 1. Differential response of 23 cotton genotypes to $C$. cassiicola, evaluated by artificial inoculation with a mixture of two cotton isolates with equal proportions under glasshouse conditions.

\begin{tabular}{cccc}
\hline & \multicolumn{2}{c}{ \% leaf area infected 10 days after inoculation } & \\
\hline Genotype & Disease severity & Genotype & Disease severity \\
\hline BRS 369 RF & $36.5 \mathrm{a}^{1}$ & TMG 41 WS & $54 \mathrm{a}$ \\
IMACD 8276 & $32.5 \mathrm{a}$ & FM 982 GL & $47 \mathrm{a}$ \\
BRS 370 RF & $37.5 \mathrm{a}$ & BRS 368 RF & $43 \mathrm{a}$ \\
DP 1228 B2RF & $45 \mathrm{a}$ & FM 944 GL & $51 \mathrm{a}$ \\
TMG 82 WS & $38 \mathrm{a}$ & FM 951 LL & $46.5 \mathrm{a}$ \\
IMA 03-1318 & $41.5 \mathrm{a}$ & FM 975 WS & $54 \mathrm{a}$ \\
BRS 371 RF & $42 \mathrm{a}$ & IAC 26 RMD & $54 \mathrm{a}$ \\
TMG 42 WS & $40.5 \mathrm{a}$ & IMA 5675 BG2RF & $60 \mathrm{a}$ \\
DP 555 BGRR & $44 \mathrm{a}$ & IMA 5672 BG2RF 966 LL & $56.5 \mathrm{a}$ \\
TMG 11 WS & $37.5 \mathrm{a}$ & & \\
TMG 81 WS & $50 \mathrm{a}$ & & \\
BRS 372 & $40 \mathrm{a}$ & &
\end{tabular}

*Average of 16 plants. Tukey 5\%; CV = 30.

Table 2. Reaction of cross-inoculations using three cotton and two soybean isolates on six cotton and two soybean cultivars, under glasshouse conditions.

\begin{tabular}{|c|c|c|c|c|c|c|}
\hline & \multirow{3}{*}{ Genotype } & \multicolumn{5}{|c|}{ Reaction of C. cassiicola isolates ${ }^{1}$} \\
\hline & & \multicolumn{3}{|c|}{ Cotton } & \multicolumn{2}{|c|}{ Soybean } \\
\hline & & IMA262 & IMA358 & IMA374 & IMA275 & IMA383 \\
\hline \multirow{6}{*}{ Cotton } & BRS 336 & $++^{1}$ & + & + & + & + \\
\hline & DP 555 BGRR & + & + & + & + & + \\
\hline & FM 975 WS & + & + & + & + & + \\
\hline & FMT 709 & + & + & + & + & + \\
\hline & IAC 26 RMD & + & + & + & + & + \\
\hline & IMACD 6001LL & + & + & + & + & + \\
\hline \multirow{6}{*}{ Soybean } & CD 214RR & + & + & + & + & + \\
\hline & FT-Cristalina & + & + & + & + & + \\
\hline & BRS Favorita RR & + & + & + & + & + \\
\hline & IMA 87112RR & + & + & + & + & + \\
\hline & TMG 132RR & + & + & + & + & + \\
\hline & BRS Valiosa RR & + & + & + & + & + \\
\hline
\end{tabular}

${ }_{+}+=$Compatible reaction. 


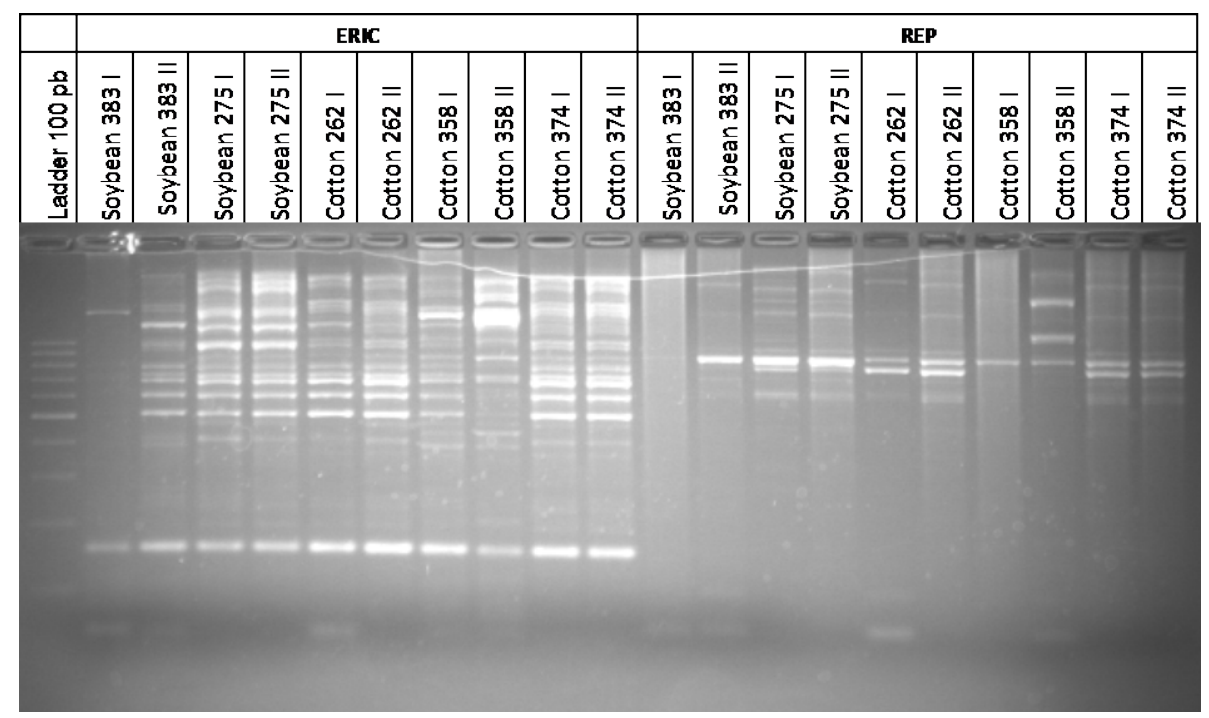

Figure 3. Amplification products of some C. cassiicola isolates from cotton and soybean obtained by ERIC/REP-PCR.

tive. Out of six, Hinf I, Alu I and EcoR I were able to cut the DNA of all the isolates in three and in two parts, respectively, but identical banding pattern was observed for all the isolates (Figure 4). Thus, both molecular techniques tested herewith indicated that the $C$. cassiicola isolates attacking cotton and soybean belong to the same strain of the pathogen in Brazil.

It is known that some isolates of $C$. cassiicola are virulent on several hosts, while others are very specific to their respective hosts [8] [9]. For this reason, distinguishing isolates based on their original host would be problematic [10].

Corynespora leaf blight of cotton can also be seed transmitted, however, the initial inoculum probably comes from the air-borne conidia from other hosts or from the left-over stubble of soybean and/or cotton. Sulfuric acid delinted seeds treated with fungicides are normally used for sowing cotton in Brazil, thereby reducing drastically the incidence of seed infection. Hot and humid weather conditions for several days favors the development of the disease epidemics.

Resistance at the cotyledon and true leaf stages was observed under glasshouse conditions for genotype PR02-77. Nonetheless, screening for resistance at both growth stages may offer more security (Figure 4). Considering the reaction of cotton genotype PR02-77 (Figure 1), it is believed that the resistance to C. cassiicola in cotton is governed by a single dominant gene, however studies related to inheritance of resistance are necessary to elucidate this fact.

Based on the pathogenicity tests, Jones (1961) [1] reported that the C. cassiicola isolates attacking cotton and soybean in the USA were identical. Results of our studies indicated that the C. cassiicola isolates from these two crops were not only fenotipically but also genotipically identical as evidenced by two molecular techniques. Considering these results, it becomes evident that immediate changes in cultural practices especially in the State of Mato Grosso, need to be taken to manage the spread and the severity of the disease. Confirmation of similarity between cotton and soybean isolates is regarded as a significant step toward management of the disease of these two crops. Epidemiologically speaking, these results increase our concern toward control of this disease in cotton as well as in soybean-especially because it is a newly immerging disease of both the crops in Brazil. There is a dire need to screen large amount of soybean and cotton germplasm for resistance from wide sources including other species of Gossypium cotton.

Since the same strain of the pathogen attacks both the crops, the present cropping system of monoculture practiced in Brazil should suffer some changes. In the southern region of Brazil, with some exception of the State of São Paulo, cotton is not grown and soybean is followed by some non-host crops such as wheat, oat or corn. Such system of soybean cultivation reduces the threat of Corynespora leaf blight not only in that region but also for the country as a whole. Nonetheless, along with varietal resistance, avoidance of growing two crops of soybean a year, and the use of fungicidal applications in soybean should receive due consideration. 


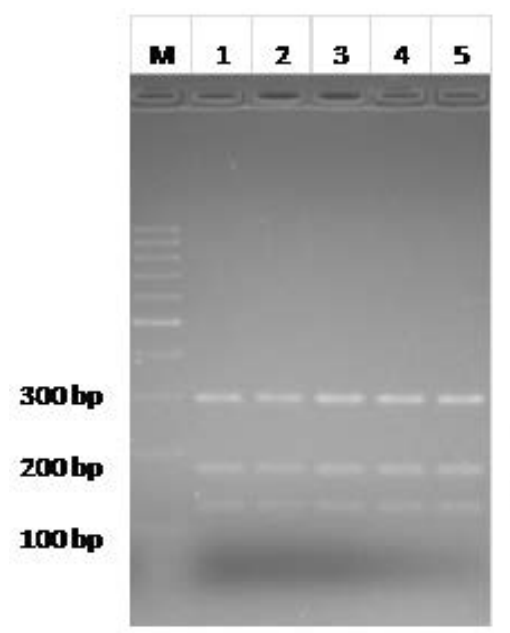

A

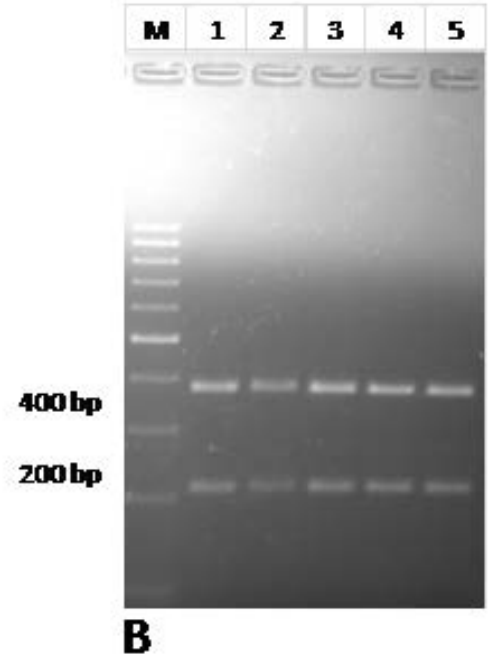

B

Figure 4. Amplification products of $C$. cassiicola isolates using restriction enzyme $\mathrm{A}=\operatorname{Hinf} \mathrm{I}$; $\mathrm{B}=$ Alu $\mathrm{I} . \mathrm{M}=100 \mathrm{bp}$ molecular marker; $1,2=\mathrm{C}$. cassiicola of soybean; $3-5=$ C. cassiicola of cotton.

In the central and the northern regions of Brazil, most of the cotton is grown in a monoculture system (soybean-cotton-soybean-cotton). Crop rotation with non-host cereal crops such as maize, millet, sorghum and wheat would help breaking the disease cycle of the pathogen. Besides, destruction of crop residue and sanitary practices during ginning and seed processing would help reduce the disease incidence and dissemination of the pathogen from one region to another. In Brazil, at present several applications of mixture of triazol and estrubilurin fungicides are being applied to control Ramularia leaf blight and no specific fungicide is being used against Corynespora leaf blight.

Integration of aforesaid measures in both cotton and soybean cultivation would help manage the disease and reduce the risk of yield losses.

\section{Conclusions}

1) Phenotypically, all isolates of $C$. cassiicola from cotton and from soybean were pathogenic to both the crops and no differentiation between them could be made;

2) Genotypically, no distingtion could be observed between the isolates from cotton and soybean;

3) With one exception, all the cotton genotypes tested so far were susceptible to $C$. cassiicola indicating that the genetic base of the cotton germplasm in G. hirsutum is very much restricted as far as this pathogen is concerned. For this reason a wider range of germplasm belonging to different Gossypium species needs to be explored for resistance;

4) Considering the monoculture system practiced in the State of Mato Grosso, involving cotton followed by soybean year after year, the disease tends to become endemic and more severe each year. Since Corynespora blight is a newly immerging disease of cotton and soybean in Brazil, integration of crop rotation with non-host cereal crops such as maize, sorghum and millet along with sanitary practices is suggested to manage the disease.

\section{Acknowledgements}

The present research was conducted under the financial support of IMA, MT, Brazil.

\section{References}

[1] Jones, J.P. (1961) A Leaf Spot of Cotton Caused by Corynespora cassiicola. Phytopathology, 1, 305-308.

[2] Conner, K.N. (2004) Alabama Cooperative Extension System. Auburn University, Auburn, 1379.

[3] Fulmer, A.M., Walls, J.T., Dutta, B., Parkunan, V., Brock, J. and Kemerait Jr., R.C. (2012) First Report of Target Spot Caused by Corynespora cassiicola on Cotton in Georgia. Plant Disease, 96, 1066. 
http://dx.doi.org/10.1094/PDIS-01-12-0035-PDN

[4] Mehta, Y.R. and Barea, G. (1994) Enfermedades de soya y su manejo. Imprenta Landivar, Santa Cruz de la Sierra, Bolivia, $87 \mathrm{p}$.

[5] Mehta, Y.R., Motomura, K.F. and Almeida, W.P. (2005) Corynespora Leaf Spot of Cotton in Brasil. Fitopatologia Brasileira, 30, 131.

[6] Dixon, L.J., Schulb, R.L., Pernezny, K. and Datnoff, L.E. (2009) Host Specialization and Phylogenic Diversity of Corynespora cassiicola. Phytopathology, 99, 1015-1027. http://dx.doi.org/10.1094/PHYTO-99-9-1015

[7] Girotto, L., Marangoni, M.S., Matos, J.N., Almeida, W.P. and Mehta, Y.R. (2013) Identification of Phenotypic and Genotypic Variability among the Isolates of Ramularia areola of Brazilian Cotton. American Journal Plant Sciences, 4, 1893-1898. http://dx.doi.org/10.4236/ajps.2013.49232

[8] Cutrim, F.A. and Silva, G.S. (2003) Pathogenicity of Corynespora cassiicola to Different Plant Species. Fitopatologia Brasileira, 28, 193-194. http://dx.doi.org/10.1590/S0100-41582003000200014

[9] Spencer, J.A. and Walters, H.J. (1969) Variations in Certain Isolates of Corynespora cassiicola. Phytopathology, 59, 58-60.

[10] Shimomoto, Y., Sato, T., Hojo, H., Morita, Y., Takeuchi, S., Mizumoto, H., Kiba, A. and Hikichi, Y. (2011) Phenotipic and Genetic Variation among Isolates of Corynespora cassiicola in Japan. Plant Pathology, 60, 253-260. http://dx.doi.org/10.1111/j.1365-3059.2010.02374.x 
Scientific Research Publishing (SCIRP) is one of the largest Open Access journal publishers. It is currently publishing more than 200 open access, online, peer-reviewed journals covering a wide range of academic disciplines. SCIRP serves the worldwide academic communities and contributes to the progress and application of science with its publication.

Other selected journals from SCIRP are listed as below. Submit your manuscript to us via either submit@scirp.org or Online Submission Portal.
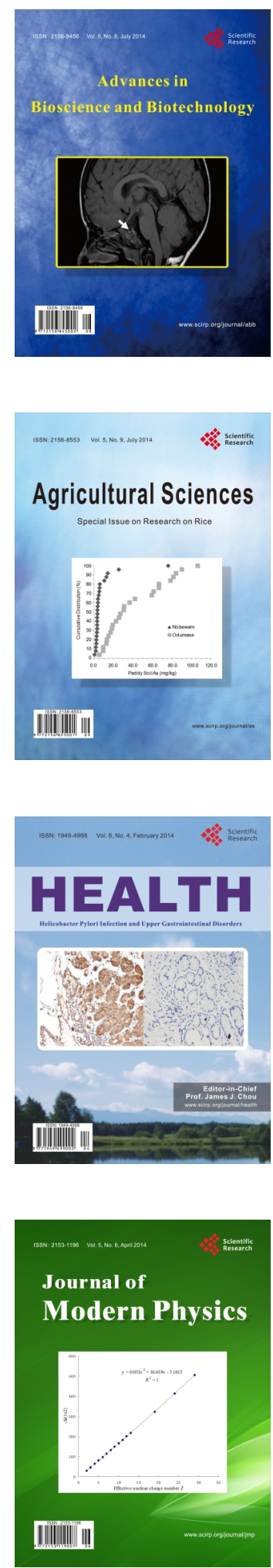
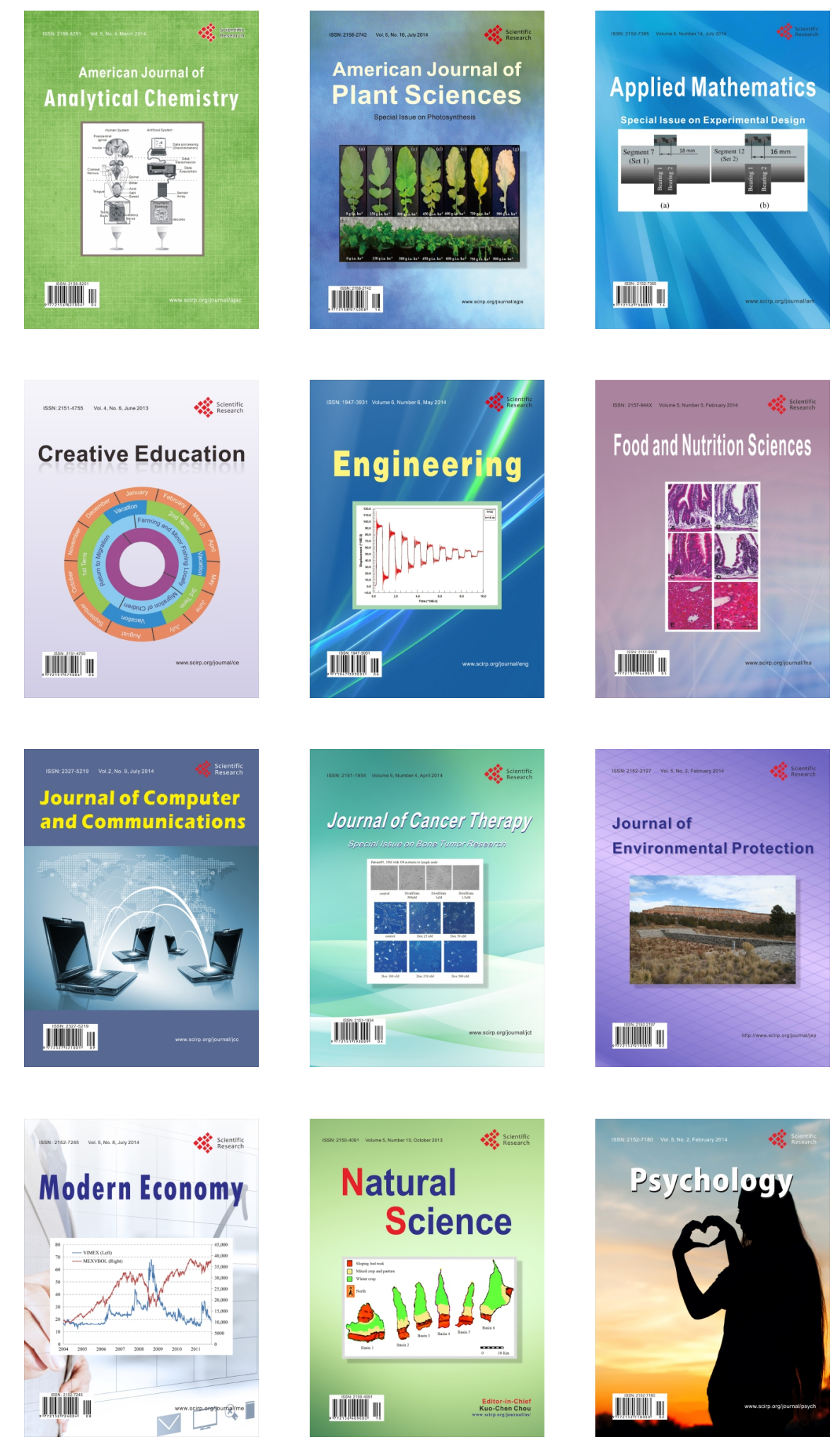